\title{
As Confissões como elogio do diálogo *
}

\author{
The Confessions in Praise of Dialogue
}

\section{Moacyr Novaes \\ Universidade de São Paulo [USP]/cnPq}

\section{RESUMO}

O artigo é a primeira parte de um trabalho que propóe ler as Confissóes como um diálogo, no conteúdo e na forma. Um diálogo pretendido (e falhado) com Deus, e também um diálogo segundo sua forma de composição. O prólogo geral da obra será apresentado como lugar de formulação de impasses teóricos, que darão unidade à investigação desenvolvida no conjunto dos treze livros. A elaboração dos impasses, já no prólogo, dependerá do uso e da crítica de modelos consagrados. Ao manejar e se distanciar de modelos retóricos e religiosos, o Autor transforma sua prece inaugural, aparentemente tradicional, em exórdio a um diálogo ainda não constituído. Ali ele disporá uma alternativa, com diretrizes cuja realização dependerá das seções autobiográfica e exegética da obra.

\section{PALAVRAS-CHAVE}

Agostinho; Confissóes; Diálogo; Narrativa; Exegese.

\begin{abstract}
This paper is the first part of a study that proposes to read the Confessions as a dialogue, in content and in form. An intended (and failed) dialogue with God, and also a dialogue according to its form of composition. The general prologue of the work will be presented as a place to formulate theoretical impasses, which unifies the research developed in the thirteen books as a whole. In the prologue, the elaboration of the impasses depends on the use and criticism of consecrated models. By manipulating and distancing himself from rhetorical and religious models, the Author transforms his seemingly traditional inaugural prayer in an exordium to a dialogue still not constituted. There he will offer an alternative, with guidelines whose realization will depend on the autobiographical and exegetical sections of the work.
\end{abstract}

\section{KEY WORDS}

Augustine; Confessions; Dialogue; Narrative; Exegesis.

* Aula inaugural pronunciada no Departamento de Filosofia da USP em 7 de março de 2017. Uma primeira versão deste texto foi apresentada como conferência na UFABC em 7 de julho de 2016. Agradeço particularmente a John Marenbom pela acolhida na Universidade de Cambridge, Reino Unido, e aos colegas e alunos do Cepame e do GT-Anpof "História da filosofia medieval e recepção da filosofia antiga". 
sine me loqui

\section{Apresentação}

As Confissóes de Agostinho são um elogio do diálogo filosófico. No proêmio da obra, o Autor exibe a necessidade de uma linguagem teórica, para corresponder ao imperativo de procurar Deus como verdade e sabedoria supremas. Para tanto, desde logo póe em questão a possibilidade mesma de diálogo com Deus, ao mostrar que são incomensuráveis a natureza de Deus — suprema verdade e infinita sabedoria - a linguagem do homem - finito e pecador. Os elementos básicos da prece inaugural, o louvor e a invocação de Deus, bem como uma tentativa renitente de prece, desembocarão numa aporia. Somente uma completa mudança de perspectiva para o uso da linguagem propiciará um caminho alternativo e propedêutico.

Formulado de início aporeticamente, o problema do diálogo pretendido entre o Autor e Deus torna-se o centro da reflexão que irá desenrolar-se nos treze livros da obra. A própria construção do problema dependerá desde logo de estabelecer distância com respeito a modelos disponíveis, tanto nas técnicas da retórica como nas fórmulas de prece religiosa. Os modelos, religiosos ou retóricos, prometem a comunicação com o deus, segundo rituais conhecidos. A afirmação do diálogo como meio de investigação, porém, será calcada no uso crítico desses modelos, especialmente na transformação de suas fórmulas, originalmente pacificadoras, em pontos de inquietação.

O elogio ao diálogo também será presente na forma do texto, se entendermos que o impasse inicial dá lugar, socraticamente, a um desvio de rota, um circunlóquio propedêutico para que o autor e seus leitores (a parte humana do diálogo falhado) venham a adquirir condições de retomar o problema, no final da obra. ${ }^{\mathrm{I}}$ A narrativa autobiográfica é a escolha para realizar o périplo socrático, de modo que a questáo inicial do diálogo com Deus seja reexaminada nos livros finais, cujo núcleo já não será a narrativa autobiográfica, mas sim a interpretação de outra narrativa, a criação do mundo segundo o livro bíblico do Gênesis.

O estatuto filosófico das Confissóes de Agostinho pode ser realçado mediante a análise de sua unidade geral. Para além do valor singular de muitas passagens, suscetíveis de análises independentes do conjunto, os treze livros da obra constituem uma reflexão contínua. Nosso propósito é exibir um problema persistente e estruturante, elaborado no seu prólogo, que deverá fundamentar a articulação geral da obra. Uma mesma tensão preside tanto os livros iniciais, assinalados pela narrativa autobiográfica, como os livros finais, em que ressalta a exegese de versículos do Gênesis. Embora exegese bíblica e narrativa pareçam alheias à análise estritamente racional, a consideração geral da obra virá indicar o seu papel na unidade de teor das Confissóes, e deverá assim elucidar escolhas formais que conferem coerência estrutural ao conjunto.

I Ver Goldschmidt (I947) \$\$ 6I-68. 
Para isso, queremos assinalar o proveito de ler as Confissóes como uma renovação do diálogo filosófico, tanto substancialmente, no desenvolvimento de conceitos e teses, como formalmente, na sua disposição argumentativa e literária. Nesta primeira parte do trabalho, o prólogo da obra (Confissóes I i I - v 6) será o foco da análise, na medida em que prepara e fundamenta a relevância de seu problema central. O resultado do prólogo não é assertivo. Ao construir uma grande aporia sobre a comunicação possível entre a criatura e o criador, os capítulos iniciais laboriosamente exibem a relevância teórica do problema do diálogo, indicando por que seu enfrentamento deverá ser feito, de início, pela narrativa autobiográfica.

\section{Platonismo e diálogo}

A filosofia nos legou o diálogo como forma ancestral de expressão. As figuras fundadoras de Sócrates e Platão associam-se ao diálogo, de tal modo que a forma pode confundir-se com o próprio platonismo. Aquela filosofia, aquele conteúdo só poderia ser expresso pelo diálogo, ou melhor, só se poderia realizar e exercer através do diálogo. A herança (ou a fortuna) de Sócrates e Platáo poderia ser reconhecida portanto no próprio uso do diálogo como forma de texto filosófico, se quisermos, como "gênero".

Este é o caso evidente de Agostinho de Hipona (354-430), ao menos do jovem Agostinho. Suas primeiras obras, de reconhecido teor platônico, são compostas como diálogos. Sabemos que os escreveu logo após abandonar a retórica como profissão, para dedicar-se à investigação filosófica. Essa verdadeira "conversão" foi interpretada como conversão em favor de uma vida estritamente filosófica, e, em particular, ao neoplatonismo (porém não ao cristianismo). Não somente o conteúdo de suas obras, mas também a escolha do diálogo como meio de investigação e expressão parecem justificar a caracterização do jovem Agostinho como neoplatônico.

No mesmo passo, porém, poderíamos interpretar o posterior abandono da forma diálogo como sinal de nova transformação de conteúdo. O neoplatonismo do jovem Agostinho cederia o lugar ao cristianismo, de modo que as velhas formas deveriam ser substituídas. Platão estava morto. Obras monográficas expositivas, comentários exegéticos da Bíblia, e principalmente os grandes títulos que fizeram o vulto histórico de Agostinho, as Confissóes e a Cidade de Deus, seriam a prova material do parricídio.

O próprio Agostinho parece corroborar esse retrato. As páginas autobiográficas das Confissóes contêm um relato do período de composição dos diálogos de juventude. Ali podemos sondar que imagem quis nos oferecer do seu passado o recém-consagrado bispo de Hipona. Em particular, interessa-nos o valor que ele atribui retrospectivamente aos seus primeiros diálogos, mediante aquele relato.

Antes de dar a palavra ao Autor, lembremos brevemente alguns dados sobre a transformação biográfica que se deu entre o verão e o outono de 386. Agostinho ocupara um posto importante na corte imperial. Decidiu abandonar o posto, onde exercia seus talentos retóricos (v. Confissóes vi vi 9), e retirou-se para uma chácara, em Cassicíaco, acompanhado de amigos e familiares. O propósito da nova vida era dedicar-se à filosofia. 
Na chácara, durante alguns dias, conduziu o grupo segundo um programa bem definido e clássico. Aproveitam a primeira luz do dia para ler e estudar o melhor da literatura romana, isto é, a Eneida de Vergílio. Depois se reúnem para discutir problemas filosóficos, seguindo uma agenda igualmente clássica: lógica, física e ética. À noite, recolhem-se no escuro para meditar (e ocasionalmente conversar).

Os debates travados por esse grupo heterogêneo foram cuidadosamente registrados (mesmo as conversas noturnas) e resultam nos chamados 'diálogos de Cassicíaco': contra academicos, de ordine, de beata uita, soliloquia. Nessas obras, podemos ler ecos das leituras de Vergílio, das ruminaçôes e debates diurnos e noturnos: afirmaçôes, reformulaçôes, contrapropostas, recuos, conciliaçóes, tudo o que compóe a vivacidade mesma do diálogo oral, forçando os limites da linguagem escrita. Como sabemos, essas obras existem até hoje e são de grande interesse filosófico. É no conjunto dessas obras que o leitor moderno encontraria, por exemplo, um precursor da revolução cartesiana: contra o ceticismo acadêmico, o conhecimento fundante de que sou, existo, conhecimento que será também núcleo do conhecimento da natureza incorpórea da alma e da prova da existência de Deus. ${ }^{2}$

Vejamos porém o que diz o autor das Confissóes (dirigindo-se a Deus, na segunda pessoa) sobre aqueles dias tão fecundos.

E chegou o dia de me livrar de fato da profissão da retórica [...], partindo com todos os meus para o campo. Os estudos que conduzi ali, já ao teu serviço, mas ainda transpirando a escola da soberba, como num intervalo de espera, são relatados em livros em forma de diálogos, entre as pessoas presentes ou comigo mesmo diante de ti (Confissóes IX iv 7). ${ }^{3}$

Isso é tudo o que ele tem a narrar sobre suas obras de juventude. A brevidade quase fala por si mesma. Nem precisaríamos nos deter em termos como "escola da soberba". O próprio fato material de, nessas poucas linhas, condensar todos aqueles dias fecundos já traduz uma apreciação que o teor das sentenças vem corroborar. Agora, se levarmos em conta o restante do relato sobre aquele período, a primeira impressão será ainda acentuada. De fato, o Livro Ix das Confissóes falará mais extensamente a respeito da estadia no campo. Mas o autor prefere destacar outro evento.

Façamos uma análise quantitativa. A menção aos diálogos [“libri disputati”] não passou de quatro linhas, ao passo que, após uma conclusão crítica sobre as "escolas de

2 Ver contra academicos III ix ss. Estude-se o excelente livro de E. Bermon (200I), Le cogito dans la pensée de saint Augustin.

3 Et venit dies quo etiam actu solverer a professione rhetorica, [...] profectus in villam cum meis omnibus. ibi quid egerim in litteris iam quidem servientibus tibi, sed adhuc superbiae scholam tamquam in pausatione anhelantibus, testantur libri disputati cum praesentibus et cum ipso me solo coram te. Traduçáo de Lorenzo Mammì, Agostinho (2017), pp. 229-230. As citaçóes das Confissóes são tomadas dessa tradução. Traduçóes de outras obras são de nossa responsabilidade. 
filosofia", o restante do relato espraia-se por cerca de noventa linhas, dedicadas a um único episódio. Agostinho medita nessas linhas ${ }^{4}$ sobre o breve momento em que cantou um pequeno salmo de David, um salmo de dez versos. Quase quatro páginas 5 sobre um momento que terá durado menos de um minuto.

O flagrante contraste quantitativo entre os dois relatos, sobre os diálogos filosóficos e sobre o canto do salmo, viria corroborar a ideia de que o bispo de Hipona renegara os diálogos de juventude, sua obra platônica, e com isso renegara o quadro mesmo da cultura clássica ("a escola da soberba", "o cheiro dos cedros das escolas de filosofia)", em favor da leitura da Bíblia. As leituras de Vergílio e os debates terão sido apenas aquela pausa arfante no combate, "transpirando [...] como num intervalo de espera", para retomar o fôlego e começar o que era verdadeiramente importante. ${ }^{6}$ A conversão, que fora filosófica, teria agora se degradado em conversão religiosa.

Mas essa não é, claro, a conclusão a que pretendemos chegar. Ao contrário, admitimos que as coisas assim se pareçam, mas a filosofia nos ensina a desconfiar das aparências. Nossa tese é que as Confissóes são antes uma renovação do diálogo, uma renovação consciente e fundada. Queremos então propor uma leitura das Confissóes como elogio do diálogo, no conteúdo e nas escolhas formais. Sócrates e Platão continuarão vivos afinal.

\section{Diálogo filosófico e uso da Bíblia}

Como primeiro passo, assinalemos que a "forma" diálogo pode ser entendida como estratégia de restituir à linguagem escrita aquela vivacidade própria ao debate oral. Ao contrário da fixação doutrinal de conteúdos, o diálogo escrito promoveria a exposição de teses, de seus contrários, ou de reavaliaçôes, conjeturas, recuos, etc. É por isso mesmo que podemos tomar o diálogo como oposto da exposição dogmática. ${ }^{7}$ Nos diálogos de juventude, encontramos essa dinâmica na alternância de vozes entre Agostinho e seus diversificados interlocutores.

Além disso, também a exemplo dos embates de Cassicíaco, o diálogo não principia pelo enfrentamento do seu problema central. De um modo geral, é preciso que os interlocutores sejam deslocados de seu pretenso conhecimento inicial, para primeiro divisarem a existência e a relevância do problema a ser enfrentado. Concerne a esse primeiro momento, antes da elaboração do problema propriamente dito, a construção de impasses com o material daquele pretenso saber inicial. Também aqui, é franca a

4 Confissóes IX iv 8-II.

5 Cf. pp. 230-234 da tradução.

6 A cronologia oferecida na edição da Bibliothèque Augustinienne, excelente aliás, assim caracteriza as atividades do período, sem menção aos clássicos: "novembre 386: Séjour à Cassiciacum. De beata uita. De ordine. Lecture des Psaumes." Euvres de Saint Augustin v. I3, Paris: Institut d'études augustiniennes, I998, p. 206.

7 Cf. Wieland (1982), \$3: Der Dialog als Medium des philosophischen Gedankens. 
oposição entre a forma diálogo e a exposição dogmática. Nossa tese é que as Confissóes são não apenas um elogio do diálogo, mas que se estruturam como um diálogo. O seu exórdio vai conduzir à elaboração do problema, que não será enfrentado logo de saída.

Mas a presença mesma de material bíblico na prece inicial da obra pode ser já um óbice a essa leitura. Com efeito, se os relatos do Livro IX contrastam os diálogos de Cassicíaco com a leitura de um Salmo, e se ainda levarmos em conta que a narrativa autobiográfica das Confissóes (que ocupa os nove primeiros livros) desemboca em "meditação sobre a lei", a saber, interpretaçâo do Gênesis (matéria dos três últimos livros, XI-XIII), temos então de perguntar que papel Agostinho, como filósofo, poderia atribuir à Bíblia, e como poderia conciliar a leitura do Gênesis com o espírito antidogmático do diálogo.

Será preciso examinar de que modo a Bíblia veio a substituir, para a formação filosófica, as fontes clássicas em geral e em particular a Eneida. Sabemos que, num plano mais geral, não apenas na biografia de Agostinho, mas também no contraste entre o legado clássico latino e o cristianismo emergente, a Bíblia viria substituir a Eneida de Vergílio. ${ }^{8}$ Essa transição parece reproduzir-se na sucessão de relatos que acabamos de mencionar: as leituras diárias da Eneida, nas tertúlias de Cassicíaco, deram lugar à leitura do Salmo 4 de David.

E inversamente, muitos também disseram que a Eneida teria sido a Bíblia dos antigos romanos.' A Eneida conteria a expressão mais bem-acabada de relatos de combate, de discursos políticos, de relatos históricos, preces e ritos religiosos, declaraçóes de amor, descrição de paisagens, exposições cosmológicas, reflexôes éticas. Vergílio, poeta irretocável, talvez até mesmo profético ${ }^{\mathrm{IO}}$, teria encontrado a fórmula do isomorfismo ${ }^{\mathrm{II}}$ entre a linguagem e o mundo, a ser imitada por todos. De tal modo que, além da consulta sistemática às soluçóes exemplares de Vergílio, fonte de educação gramatical e retórica, modelo perfeito a imitar, os romanos praticavam sortilégios com seus versos, isto é, sorteavam sentenças de sua obra em busca de resposta a problemas de natureza pública ou da vida cotidiana. ${ }^{\mathrm{I}}$

Parece mesmo que a Bíblia terá ocupado esse lugar para muitos cristãos: modelo, sobretudo modelo moral, e fonte de orientaçôes práticas, de modo que ela também será

8 "[Agostinho] deixou implícito que os cristãos também tinham um clássico tão inesgotável e absorvente quanto eram Virgílio ou Homero para os pagãos. Também a Bíblia cristá podia formar um homem" (Brown, 2005, p. 327).

9 "but the authority of Vergil was supreme, and his poetry was, so to speak, the Bible of the ancients" (Comparetti, I966, p. 32).

Io Ao se ler a sua Écloga IV como prenúncio da vinda de Cristo. Cf. Comparetti, I966, pp. 99-I08. Agostinho discute o assunto na Cidade de Deus x 27.

II Cf. Macróbio, Saturnalia v I 19-20. Cf. Lim, Augustine, the Grammarians and the Cultural Authority of Vergil, in Rees, 2004.

I2 Mastrocinque, Creating One's Own Religion: Intellectual Choices, in Rüpke, 2007, pp. 378-39I: "Verses of Virgil were used as a divinatory device: the sortes Vergilianae (Scriptores Historiae Augustae, Hadrian 2; Alexander Severus I4)", p. 385. 
objeto de "sortes". ${ }^{13}$ Trata-se então de duas equiparações semelhantes. A Bíblia como a nova Eneida, ou a Eneida como a Bíblia dos antigos romanos. A semelhança reside no uso de ambos os livros como compêndio universal. Dizer que a Bíblia viria a ser a Eneida dos cristãos implica pois assumir que esse era o seu papel: fonte perfeita e exemplar. ${ }^{14}$

Mas não para todos. Seguramente, não para Agostinho. Com efeito, a crítica aos modelos clássicos, e a consequente "substituição" da Eneida pela Bíblia, em Agostinho, vai na contramão de um movimento dogmatizante. O valor e a utilidade que têm para ele as "sagradas escrituras" decorre em grande medida de suas imperfeiçôes. É na verdade a falta daquele isomorfismo com o mundo, tal como se buscava na poesia, e Vergílio teria alcançado, o que dá relevância a essa obra, e a exemplo dela, a todo outro texto. Por isso ao falar em "substituir", náo podemos entender meramente ocupar o mesmo lugar. Talvez seja mais adequado dizer que Agostinho pretende esvaziar aquele lugar do texto perfeito, pela análise da Bíblia como obra suscetível e promotora de diálogo.

\section{A Bíblia nas Confissões}

Esse uso das "escrituras" tem lugar logo nas primeiras linhas das Confissões. Desde logo, o leitor depara com a inquietação humana, ali apresentada pela pretensão frustrada de estabelecer diálogo com Deus. ${ }^{\mathrm{IS}}$ Com base em textos que exibem a inefabilidade divina, ou melhor, que exibem a incongruência entre os recursos expressivos humanos e a natureza transcendente de Deus, o Autor dá à prece de abertura de sua obra um teor paradoxal. A obra parece fora do alcance humano, afinal. Assim que começam, as Confissóes desafiam as suas próprias condiçôes de possibilidade. É justo dizer que a inquietação não é apenas apresentada. O papel do prólogo é efetivar a inquietação, mediante as aporias do louvor e da invocação, como veremos a seguir. No remate do prólogo, o tema será retomado: "Quem me fará repousar [adquiescere] em ti??" (Confissóes I v 5). ${ }^{16} \mathrm{~A}$ inquietação ainda não resolvida introduzirá o esforço de comunicação com Deus.

Desde as palavras iniciais, o texto trata de produzir inquietação:

(I) Tu és grande, Senhor, e demais louvável. Grande é tua potência, e tua sabedoria é inumerável. (2) E quer te louvar um homem, fragmento qualquer de tua criação, e um homem que anda em círculos carregando sua mortalidade, que anda em círculos carregando a prova de seu pecado e (3) a prova de que tu resis-

I3 Para compreender o emprego de sortilégios bíblicos no cristianismo, Courcelle, além de mencionar práticas "pagãs", examina também a importância da tradição judaica: Courcelle (I952) e id. (I963), cap. vir. A despeito de alusóes aos sortilégios bíblicos, por intérpretes da cena do jardim no Livro viII das Confissóes, observe-se que Agostinho não parecia adepto das "sortes”: v. epistula LV xx 37.

I4 Testemunho tardio da confusão entre a Eneida e a Biblia seriam, já no século v, as Saturnalia de Macróbio: "de manual didático, Virgílio poderia transformar-se, como a Bíblia, numa fonte inesgotável de informaçóes religiosas", (Brown, 2005, p. 375). Cf. Markus, Paganism, Christianity and the Latin Classics in the Fourth Century, in Binns, I974, p. II, "Vergil (their bible)", em referência ao "círculo de Símaco" (p. 9).

I5 Sobre o "diálogo pela metade" (halbierte Dialog), estude-se o excelente artigo de Herzog (1984).

I6 "quis mihi dabit adquiescere in te?" 
tes aos soberbos; e ainda assim quer te louvar um homem, fragmento qualquer de tua criação. (4) Tu incitas a que seja uma delícia te louvar, porque nos fizeste rumo a ti e nosso coração é inquieto, até aquietar-se em ti (Confissóes I i I). ${ }^{17}$

Podemos dizer que o paradoxo se acumula em "camadas" (segundo a numeração que introduzimos na citação). Primeiro, as primeiras duas sentenças podem ser lidas como internamente contraditórias. A afirmação da grandeza de Deus é "corrigida" pela advertência de que o louvor é inesgotável. "Demais louvável" é aquilo cujo louvor ultrapassa toda medida, de modo que dizê-lo "grande" resulta insuficiente, ou até mesmo falso. O mesmo contraste ocorre entre afirmar que a potência é "grande", e em seguida afirmar que a sabedoria é "inumerável”. Novamente, a quantidade é tanto afirmada, quanto denunciada como categorialmente em falso.

$\mathrm{Na}$ segunda camada, sobrevém a vontade humana. Não bastasse a natureza excelente do objeto de louvor, o enunciador do elogio é por sua vez rebaixado. Em contraste com a grandeza inumerável, o fragmento qualquer é ainda rebaixado numa queda progressiva. A anáfora ${ }^{18}$ da terceira sentença ("Quer te louvar...") exibe um rebaixamento progressivo; a repetição sucessiva dos termos - "homem", "anda em círculos carregando" e "prova" — , a cada passo introduzindo um novo complemento negativo - "anda em círculos", "mortalidade", "prova", "resistes" — , vai exibindo a profundidade negativa da condição humana, da criatura que quer louvar mas é muito pequena para a tarefa. No final dessa longa sentença paratática, o remate com a advertência contra a soberba.

O terceiro elemento, ou camada, é agora a interdição da soberba. Deus paradoxalmente não-louvável, homem paradoxalmente desejoso de louvar, e a interdição da soberba humana por Deus. A vontade persistente de louvar arrisca-se à soberba, colidindo com resistência de Deus. Como o leitor descobrirá paulatinamente na narrativa autobiográfica e na reflexão moral do Livro $\mathrm{x}$, a soberba será uma barreira fundamental a superar, em especial para lograr o intentado diálogo com a verdade.

Ora, a camada seguinte (4) acrescenta novo problema, que contrasta em bloco com o conjunto precedente. O Autor intensifica o paradoxo ao lembrar que é o mesmo Deus que incita ao louvor humano: criador infinitamente (não)-louvável, criatura pequena e pecadora, interdição pelo criador à soberba da criatura, e finalmente, criação como ato que incita a criatura a gostar de louvar o criador e a buscá-lo. A tensão gerada pelo imperativo de louvor repercutirá no final da prece introdutória: após reiterados fracassos na comunicação humana com Deus, é ele mesmo quem ordena o amor humano (v. Confissóes I v 5).

I7 "Magnus es, domine, et laudabilis valde. magna virtus tua et sapientiae tuae non est numerus. et laudare te vult homo, aliqua portio creaturae tuae, et homo circumferens mortalitatem suam, circumferens testimonium peccati sui et testimonium quia superbis resistis; et tamen laudare te vult homo, aliqua portio creaturae tuae. tu excitas ut laudare te delectet, quia fecisti nos ad te et inquietum est cor nostrum donec requiescat in te." Aqui renunciamos a reproduzir integralmente a elegância da tradução de L. Mammì, para sublinhar alguns aspectos formais.

I8 $\mathrm{O}$ uso da anáfora pode ser examinado à luz da técnica do sermo humilis, cuja importância para Agostinho, sobretudo como leitor da Bíblia, foi apontada por Auerbach (20I2). O efeito de rebaixamento é coerente com a escolha da forma paratática para o texto, própria ao registro humilde. 


\section{Centão de louvor}

Os problemas tornam-se mais agudos, se reconhecermos que o paradoxo é exibido mediante a combinação de citaçôes e alusões bíblicas. Seria possível apresentar as linhas iniciais das Confissóes como um verdadeiro centão, a exemplo de homerocentóes e vergiliocentôes: composiçóes geralmente paródicas, cujo material eram versos de Homero ou de Vergílio. ${ }^{19}$ Aqui, trata-se também da composição a partir de textos já conhecidos, recortados e recombinados, todavia um centão bíblico, isto é, uma costura de passagens bíblicas, sem praticamente nenhuma palavra própria ou 'original' do autor. ${ }^{20}$

Mas o centão de Agostinho, ao justapor sentenças bíblicas, não resulta em paródia. Se os centôes em geral devem ter efeito de distanciamento com respeito ao "original", de forma paródica ou até mesmo picaresca, aqui será outro o distanciamento quanto à fonte. Trata-se de usar o texto de base como material para interrogação teórica. Por isso, o centão bíblico de Agostinho, sem ser picaresco ou paródico, tampouco resulta em um conjunto dogmático afirmativo. $\mathrm{Na}$ verdade, as sentenças parecem contradizer-se (internamente ou entre si) e o centão exibirá uma aporia.

Com isso, temos o primeiro testemunho de um uso preciso das chamadas "escrituras sagradas": ao invés de fornecer soluçóes afirmativas e dogmáticas, base para uma prece tradicional, a Bíblia propiciou a composição de um impasse, que dará ocasiáo à exposição do problema que vai atravessar o conjunto dos treze livros das Confissóes. Que o texto bíblico seja tomado como verdadeiro, axiomaticamente, apenas realça a importância do impasse inicial: um conjunto de sentenças verdadeiras que prima facie conforma um paradoxo.

Tal uso do texto bíblico não pretendia ser original. Agostinho atribuirá à própria Bíblia esse recurso transformador da leitura. Nas mesmas Confissóes encontramos o reconhecimento do texto bíblico como modelo para sua composiçáo paradoxal. A “absurdidade" está propositalmente em passagens das Escrituras, combinada a passagens claras e acessíveis aos espíritos mais simples, assim "atiçando a atenção daqueles que não têm coração leve". ${ }^{21}$ Ao longo das Confissóes o leitor voltará a deparar com enigmas — talvez o enigma do tempo no livro XI seja o mais célebre —, igualmente articulados com o uso de passagens bíblicas. Dado esse primeiro embate com as palavras bíblicas, na busca de precisão conceitual e uso teórico da linguagem, o filósofo terá de aprender outro modelo expressivo, distante do isomorfismo vergiliano. ${ }^{22}$

I9 Sandnes (2011), e Pollmann, Sex and Salvation in the Vergilian Cento of the Fourth Century, in Rees, 2004 .

$20 \mathrm{Na}$ passagem citada acima não destacamos em itálico as citações bíblicas textuais. Nosso intento é evitar o contraste com as passagens que, mesmo não sendo citaçóes exatas, são claras alusóes a outros textos bíblicos. Desse modo, o trecho pode ser lido em conjunto como um centão de citaçóes e alusóes. Cf. Salmo 48 (47), I; Salmo I47 (I46), 5, Primeira Epistola aos Coríntios I, 24; Segunda Epistola aos Corintios 4, IO; Provérbios 3, 34.

2I Confissóes vi v 8. "absurditatem [...] exercens intentionem eorum qui non sunt leves corde".

22 Pace Mohrmann, 1955, p. 244, que julga haver procedimento semelhante em Vergílio, pelo espelhamento entre antíteses cósmicas e literárias. 


\section{Louvor e invocação}

O problema ainda não está completamente enunciado. Para que venha a ser tomado como um desafio ao diálogo, o conflito inicial será desdobrado: de uma questão de linguagem, as aporias atingirão a consideração da relação real entre o homem e Deus, isto é, a relação entre o ser do homem e o ser de Deus. Com efeito, para aprofundar a apresentação da sua aporia inicial, a partir da expectativa de comunicaçáo com Deus mediante uma prece, o Autor desloca o assunto das condiçóes do louvor para as condiçôes da invocação.

Uma vez que o louvor oferece dificuldade, ele pergunta: "Concede-me, Senhor, saber e compreender o que é anterior: invocar-te ou louvar-te?” (Confissóes I i I) Desse modo, inicia uma análise regressiva, em busca dos pressupostos para o louvor já problematizado. A pergunta sobre a relação entre louvar e invocar vai levar a novas perguntas, de modo que o tema da invocação adquira centralidade, inaugurando a segunda alínea do livro. "E como invocarei o meu Deus, meu Deus e Senhor [...]?" (Confissóes I ii 2). ${ }^{23}$

A presença desses temas, louvor e invocação, já na abertura das Confissóes poderia por a perder a natureza filosófica da obra. Compor o início como uma prece, com citações bíblicas e patentes recursos retóricos, poderia ser a reafirmação de duas velhas inimigas da filosofia, a retórica e a religiấo. Porém, justamente porque louvar e invocar um deus são antes práticas tradicionais romanas (tanto da religião civil politeísta, como do monoteísmo cristão), presentes na poesia, na oratória e nos ritos religiosos, é que seu uso peculiar ganha importância aqui.

Ao invés de meramente compor uma prece com base em topoi familiares ao leitor, o Autor transforma louvor e invocação em problemas teóricos, de sorte a mobilizar a inquietude de seu leitor (o leitor moderno, igualmente, se não projetar sobre um texto do final do século IV aquilo que esperaria de um bispo medieval ou moderno). Ao apresentar esse impasse inicial, queremos realçar que se trata aqui, para o Autor, de uma crítica à retórica e à religião. Sem essa crítica, as Confissóes não seriam uma obra filosófica; dali é que surgirão o problema do diálogo e o seu elogio. Ao passo que retórica e prece religiosa podem ser instrumentos para pacificaçáo e quietude, aqui o papel da peculiar oratória religiosa agostiniana é amplificar teoricamente ("scire et intellegere") a inquietude, remetida a um repouso distante, ainda sequer entrevisto.

\section{Retórica}

Comecemos pela retórica. É patente a presença de artifício retórico nessa confissão de incomensurabilidade, seja entre o autor e a magnitude da tarefa proposta, seja entre o discurso de elogio e o destinatário do elogio. Na verdade, o gênero demonstrativo, ou epidítico, oferece o molde para a combinação de louvor (do criador) e acusação (da

23 "da mihi, domine, scire et intellegere utrum sit prius invocare te an laudare te" (I i I). "et quomodo invocabo deum meum, deum et dominum meum [...]?” (I ii 2). 
criatura). ${ }^{24}$ Em particular, podemos ler o texto como calcado no modelo do discurso panegírico, no qual o orador se refere à pessoa elogiada (uma elevada autoridade pública, por exemplo), e reconhece a própria pequenez em face daquele que mereceria múltiplos superlativos e até mesmo os atributos "senhor" (dominus) e "divino". ${ }^{5}$ Mas como mostra L. Mammì no prefácio à sua tradução, mesmo que claramente formulado com base nas técnicas do panegírico, o problema ganha aqui novo contorno: "uma densidade filosófica que os manuais certamente não previam" ${ }^{26}$

A presença da retórica prenuncia a discussão que Agostinho conduzirá sobre a sua própria formação literária e filosófica. $\mathrm{O}$ manejo das técnicas da eloquência indica que, no conjunto da obra, o autor encontrará um uso legítimo, ainda que o faça com base numa crítica de suas fontes, como Cícero, Vergílio e Terêncio (conforme o leitor descobrirá logo no Livro I). Nesse primeiro parágrafo da obra, a par dos impasses da linguagem, os recursos da parataxe (como antíteses e anáforas) não apenas revelam o aprendizado com o sermo humilis bíblico. ${ }^{27}$ Trata-se de saber que o uso legítimo das palavras requer trabalho de interpretação e propósito teóricos.

As antíteses são mobilizadas com o fim de produzir distanciamento entre texto e leitor. $\mathrm{O}$ procedimento difere da mera contradição interna, própria às inconsistências intencionais do panegírico ${ }^{28}$ ou à natural imprecisão conceitual da linguagem poética ou mítica. Assim é que, ao criticar as escolas de retórica, Agostinho menciona a literatura (Terêncio) que apresenta ambiguamente o maior deus olímpico: "Júpiter senhor dos trovóes e dado a amores ilícitos?”. O problema, para uso teórico da linguagem, é que nesse caso se trata de mera contradição. "Embora não pudesse fazer as duas coisas ao mesmo tempo, fingiu-se que sim" (Confissóes I xvi 25). ${ }^{29}$ A ficção, nesse caso a comédia romana, por desconhecer ou negligenciar que náo convém ser ao mesmo tempo adúltero e tonitruante, produz apenas um contrassenso, e não um paradoxo filosoficamente relevante.

\section{Religião}

Se temos razáo em associar ao modelo de discurso epidítico os impasses do louvor e da autoacusação, ao mesmo tempo em que assinalamos o distanciamento procurado por Agostinho, haverá movimento semelhante com respeito à religião. O leitor reconhecerá a oratória e o tom religioso, e poderá ler o início da obra como sua prece inaugural. Num sermão de explicação de Salmo, o próprio Agostinho testemunha a associação costumeira entre louvor e invocação nas preces religiosas: "feito primeiro o louvor, é

\footnotetext{
24 "Demonstrative rhetoric is the theory of verbal praise (laudatio) and blame (vituperatio)." DiLorenzo (1983) p. I25, que envia a Cícero, De inventione I v 7.

25 "In all of the Panegyrici, divinus is the adjective which the orators most commonly use to describe things both celestial and imperial." (Rodgers, I986, p. 7I).

26 Confissóes, prefácio de L. Mammì, p. 20.

27 V. referência a Auerbach, à nota is supra.

28 Cf. Maguinness (1933).

29 "Et tonantem Iovem et adulterantem? et utique non posset haec duo, sed actum est".
} 
costume seguir-se a invocação" $3^{\circ} \mathrm{O}$ sermão ainda mobiliza citaçôes de outros Salmos — Sl. I8 (I7), 4 e Sl. 75 (74), 2 - como registros bíblicos da mesma articulação entre o louvor e a invocação. $\mathrm{Na}$ verdade, a combinação não parece sequer específica da prece cristã: os ritos da religiáo civil romana também continham fórmulas de louvor e invocação do deus, como parte integrante das preces..$^{31}$

Mas não convém trivializar o louvor e a invocação no exórdio das Confissões. Exatamente porque são fórmulas conhecidas da oratória e dos ritos religiosos, o fato de louvor e invocaçáo serem apresentados como parte de uma grande aporia confere sentido diferente ao seu uso. O prólogo das Confissóes adverte o leitor para a possibilidade, na verdade, para a necessidade de encontrar sentido especulativo naquilo que pode parecer banal. Desse modo, as dificuldades elaboradas requerem uma análise das condiçóes necessárias ao louvor de Deus, conduzindo à formulação do problema fundamental da obra.

\section{Invocação e conhecimento(s)}

Em primeiro lugar, trata-se de mostrar o lugar central da invocação, para depois examinar por que também ela oferece dificuldades, a exemplo do louvor. Nesse novo plano, a aporia já não será estritamente verbal: veremos que os paradoxos da invocação concernem à relação real entre o homem e Deus. A invocação impossível desafiará o diálogo pretendido. $\mathrm{O}$ esforço de expor as dificuldades teóricas envolvidas resulta em dimensionar corretamente os problemas, e prepara o seu enfrentamento no decorrer da obra.

A passagem do louvor à invocação, como nova sede dos problemas, requer o uso de uma citaçáo bíblica: Carta aos Romanos IO, I4. Inicialmente, a dúvida concerne à precedência entre o conhecimento e os elementos tradicionais da prece (louvor e invocaçáo). O conhecimento é condição ou resultado da prece? Invoca-se por conhecer ou invoca-se para conhecer?

Concede-me, Senhor, saber e compreender o que é anterior: [...] conhecer-te ou invocar-te? Mas quem poderia te invocar, se não te conhecesse? Não te conhecendo, poderia invocar outra coisa. Mas não te invoca, ao contrário, para te conhecer? (Confissöes I i 1) ${ }^{32}$

Para superar a dificuldade, o autor recorre à distinção que encontra na Carta de Paulo aos Romanos: invocação é situada como ponto de articulação de duas formas distintas de conhecer (scire). Uma forma é requerida para a invocação do deus: não posso invocar se ignorar (nesciens) o destinatário do discurso.

30 "Praemissa enim laude, invocatio sequi solet". Enarratio in Psalmum io4, I.

$3 \mathrm{I}$ "The structure of Cato's petition is typical of Roman prayers of all types. It opens with an invocation of the god ("Mars"), including honorific epithets ("father"). Here could be added descriptive phrases to more carefully identify or praise the deity." Halm, Performing the Sacred: Prayers and Hymns, in Rüpke, 2007, p. 240. "Every complete formal prayer [...] does include an invocation." (Hickson, 1993, p. 33)

32 "da mihi, domine, scire et intellegere utrum [...] scire te prius sit an invocare te. sed quis te invocat nesciens te? aliud enim pro alio potest invocare nesciens. an potius invocaris ut sciaris?" 
O problema da ignorância do deus na invocação também ocorre no rito religioso: "qual Deus não sei ao certo", reconhece Evandro no canto viII da Eneida. Mas a solução politeísta não dependia de uma reflexão teórica. Em situaçôes de dúvida quanto ao deus ou ente lendário que mereceria o rito (um sacrifício, por exemplo) ou sobre de que modo dirigir-se a ele, ${ }^{33}$ o deprecante tinha recursos como invocar vários deuses e deusas, ou dirigir-se genericamente ao deus ou deusa pertinente, reconhecendo não saber exatamente de quem se tratava, ou ainda empregar fórmulas descritivas sem um nome específico. ${ }^{34}$

Agora, tomada a invocação como problema conceitual, e não meramente ritual, a incerteza torna-se um problema de conhecimento. A primeira forma de conhecimento a ser mobilizada será a crença. Notemos que articular um ato religioso, a prece invocatória nesse caso, a um "credo", com conteúdo assertivo, já é passo de distanciamento com respeito à religião tradicional. $\mathrm{Na}$ religião civil, bem como no cristianismo praticado por cristãos como Mônica, a religião se resolve nas formas cerimoniais de culto (cf. Confissóes VI ii 2), dissociadas de corpus assertivo e insuscetíveis de investigação teórica. ${ }^{35}$

Mas aqui, quem faz a prece, deve antes crer, dar assentimento ainda que precário a algum conteúdo assertivo, para somente então invocar. Porque foi anunciado por outrem, Deus deve ser de algum modo conhecido, antes de ser invocado (e entáo louvado). "Porém, como invocarão os que não acreditam? Ou como acreditarão, se ninguém anunciou?" (Confissóes I i I ${ }^{36}$

Como ação da criatura racional, os limites dessa forma são patentes. Crer não é o conhecimento pleno que se almeja. Enquanto acreditar é condiçáo para invocar, uma segunda forma de conhecimento deve ser propiciada pela invocaçáo: quem invoca quer vir a conhecer o destinatário (ut sciaris), e com isso espera ainda vir a ser capaz de louvá-lo mais adequadamente. Já distante das formas rituais de prece, o valor da invocação reside em introduzir no texto um movimento capital para o conjunto das Confissóes. De um lado, como condição prévia, conhecer é acreditar, ter fé. De outro lado, a invocação explicita o caráter prospectivo da fé, isto é, usa a fé como forma de conhecimento em vista de outra (e melhor) forma de conhecimento.

Nos termos dessa passagem, a invocaçáo introduz o par procurar/encontrar (quaero/ inuenio). ${ }^{37} \mathrm{O}$ conhecimento prévio pela fé relança o problema, mediante a prece invocatória. Trata-se verdadeiramente de dar início a uma investigação de como comunicar-se com Deus. Para isso, o Autor acrescenta outra citação bíblica, o Salmo 22 (2I), 27, e uma alusão a Mateus 7, 7, de modo a retomar o tema do louvor, das condiçóes para um louvor

33 Para a diferença, nas práticas romanas, entre deus e ente lendário, v. Bailey (1969).

34 "quis deus incertum est" (Eneida viII 352). cf. Hickson, op. cit. Capítulo II: The Invocation.

35 "Rappelons-nous qu'il n'existait ni catéchisme ni sermon dans le culte romain". (Scheid, 20II, p. 279). Quanto aos cristáos, o de doctrina christiana de Agostinho logo de início menciona e enfrenta os adversários de uma abordagem teórica do cristianismo e da Bíblia.

36 "quomodo autem invocabunt, in quem non crediderunt? aut quomodo credent sine praedicante?"

37 O exame dos problemas relativos ao binômio procurar/encontrar, presentes em toda a obra, deverá esperar o Livro x das Confissóes. 
agora conjugado no futuro: "E louvarão o Senhor os que o procuram. Quem o procura encontra-o, e quem o encontra louvá-lo-á." (Confissóes i i I ${ }^{38}$

No lugar intermediário entre duas formas de conhecimento, a invocação é condição para o louvor, invertendo o sentido costumeiro. ${ }^{39}$ A procura iniciada com a invocação poderá ensejar o encontro de Deus, e então o seu louvor. Em suma, o problema do louvor é transformado no problema da invocação, cuja caução preliminar é acreditar.

Que eu te procure, Senhor, invocando-te, e te invoque acreditando em ti: com efeito, foste anunciado. Invoca-te, Senhor, a minha fé, que tu me deste, que me inspiraste pela humanidade de teu Filho e pelo ministério de teu anunciador (Confissóes I i $\mathrm{I}) .^{40}$

\section{Invocação: da linguagem ao ser}

Como dissemos, ao deslocar o problema para a invocação, Agostinho apresenta as incongruências da sua prece em novo terreno. Já não se trata somente da linguagem: a relação entre o ser de Deus e o ser do homem é também paradoxal. Porque requer conhecimento, e conhecimento como intelecção, a invocação tem de ser esclarecida. Na verdade, em face das dificuldades elaboradas nesse exórdio, o tema permanecerá relevante para toda a obra, como atesta o início do último livro: "Invoco-te, meu Deus" (Confissóes xirI i I).

Em primeiro lugar, a análise etimológica do termo (elementar, aliás) ${ }^{4 \mathrm{I}}$ tem primeiro que ser coerente com a discussão sobre o louvor, e rejeitar presença espacial de Deus no homem. Se Deus não pode estar em mim com em um lugar, a questão é refeita: como explicar a presença desejada de Deus, levando em conta sua transcendência? Como poderia o homem "captar" Deus, em vista da incongruência categorial entre os seres de um e de outro?

A tensão entre os dois termos, presença e transcendência, vai mover a reflexão, de modo quase aporético, isto é, de modo a que novamente uma saída pareça impossível, e a invocação da relação real entre homem e Deus se veja obliterada. Com efeito, a ideia mesma de invocação colide com a presença divina, na medida em que uma primeira análise mostra que a presença divina tem de ser pensada e interrogada como onipresença.

Desse modo, o problema com a invocação é que ela parecerá simplesmente ociosa, quer eu considere que "captar" a presença de Deus é um modo de expressar minha própria existência (Deus existe em mim: porque tenho o ser, e náo o teria sem Deus), quer considere, inversamente, que a presença significa que a criatura é que está em Deus, porque é ele o criador da totalidade dos seres. Assim, de um lado toda mera existência, e toda condição de existência, já contam com a onipresença divina: "mesmo se descer

38 "et laudabunt dominum qui requirunt eum: quaerentes enim inveniunt eum et invenientes laudabunt eum."

39 V. supra a Enarratio in Psalmum IO4, I (nota 3I).

40 "quaeram te, domine, invocans te et invocem te credens in te: praedicatus enim es nobis. invocat te, domine, fides mea, quam dedisti mihi, quam inspirasti mihi per humanitatem filii tui, per ministerium praedicatoris tui."

4I In-vocar significa "chamar para dentro". 
no inferno, tu lá estás". ${ }^{22}$ De outro, como poderia o homem estar distante de Deus, distanciar-se de sua onipresença, que 'preenche céu e terra.'?

$\mathrm{Na}$ verdade, a exposição desses dois modos de entender a presença, Deus no homem ou o homem em Deus, em princípio como alternativas, vai conduzir à exposição de duas exigências, cada uma com suas dificuldades próprias, cuja reunião será por sua vez um novo enigma. Deus tem presença ubíqua, e já está também dentro de mim, e/ou abarca a totalidade da criação, de modo que cada criatura é que está nele. Nos dois casos, ao tomar a presença como onipresença, esvazia-se o próprio sentido da prece invocatória. Mas o que é agora a onipresença divina? As perguntas sucedem umas às outras, sem que as precedentes estejam esclarecidas. A sucessão de perguntas sugere um trabalho infinito, como se o autor andasse "em círculos carregando sua mortalidade". Como articular a totalidade da onipresença à totalidade das criaturas?

\section{0 conteúdo continente}

Preparando a torrente de antíteses da prece que ainda virá, a onipresença é apresentada como uma contradição em termos. Totalidade e presença, reunidas na mesma palavra, mal se acomodam uma à outra. $\mathrm{O}$ argumento trata primeiro de explorar o vocabulário espacial, ainda que insuficiente, para destacar elementos envolvidos que requerem explicação conceitual. Em seguida, uma nova série de perguntas traduzirá a questão em novo plano.

Primeiro, a totalidade da criação não poderia "captar" a presença do deus invocado, demais louvável e inumerável. Mas, afirmada a presença total de Deus, como então caracterizar o excesso, o que "sobra" de Deus, sem incorrer em espacialização? Presença total e demasia têm de ser pensados de outro modo. Se céu e terra não captam Deus, mas algo sobra, o seu preenchimento não poderá ser mediante o vocabulário de conteúdo e continente. Por isso, a tensão é exibida mediante um oximoro (ou uma série de oximoros): Deus é um “conteúdo continente”. Deus é conteúdo da criação (porque a preenche), sem porém ser por ela contido; ao contrário, é ele que a contém, na medida em que lhe dá ser e estabilidade. ${ }^{43} \mathrm{~A}$ "sobra" é o transbordamento da transcendência que não permanece fechada sobre si mesma, mas move-se em favor da criatura.

A compreensão e a explicação movem-se forçosamente no campo das negativas, porque nenhum termo pode ser tomado segundo seu sentido usual. A interpretaçáo tem de dar conta daquele paradoxal movimento favorável, combinação de transcendência e presença: “[...] não são os vasos plenos de ti que te tornam estável: mesmo que eles sejam quebrados, tu não derramarias. E quando derramas sobre nós, não desces, mas nos levantas; não te dispersas, mas nos recolhes" (Confissóes I iii 3). ${ }^{44}$

42 "etsi descendero in infernum, ades." Cf. Salmo I39 (I38), 8.

43 O tema da estabilidade será capital na metafísica do ato criador. Ali o Autor encontrará a tríade de doação de ser, ordenação pela forma, e garantia da estabilidade no ser e na forma.

44 "non enim vasa quae te plena sunt stabilem te faciunt, quia etsi frangantur non effunderis. et cum effunderis super nos, non tu iaces sed erigis nos, nec tu dissiparis sed conligis nos." 
O temário da obra vai se enriquecendo. A importância da ação divina, já no ato criador, e o lugar metafísico do homem no conjunto de céu e terra deverão ser o núcleo da análise do Gênesis, no final da obra, onde se espera justamente a realização do verdadeiro diálogo. Por ora, as peças vão sendo dispostas no tabuleiro.

Para recusar a espacialização, restaram fórmulas negativas, que ainda não esclarecem propriamente a onipresença. Na verdade, a aporia renova-se pela tradução do problema como contraste entre duas totalidades. Uma sentença afirmativa anuncia um novo enigma a ser explicado: "Mas tudo o que preenches, o preenches da totalidade de ti" (ibid., grifos nossos). ${ }^{45}$ Trata-se de explicar essa dupla totalidade, ou a relação possível entre totalidades distintas.

Todas as coisas juntas (omnia), estão aquém do ser de Deus. Como então poderiam captar a totalidade (toto) de Deus? Duas hipóteses são formuladas, mas merecem claramente respostas negativas. Captariam todas simultaneamente uma parte da totalidade divina, e a mesma parte? Isso responderia por certa presença total de Deus: em todas as criaturas e a mesma "totalidade". Mas não basta, porque a presença de Deus não é parcial; ele deve ser pensado em tudo, e como presença total. Ou, para captar tudo, captariam então de modo distribuído, em partes diversas, segundo as respectivas capacidades? Ora, nesse caso, Deus seria captado ao ser repartido em partes maiores e menores? Novamente, a totalidade divina não é preservada pela totalidade das coisas. Por ora, a interrogação é capaz apenas de explicitar as exigências conceituais, sem respondê-las. A terceira hipótese é na verdade a explicitação dos termos do problema, que permanecerá em aberto: "Ou estás todo em todo lugar, e nada te contém inteiramente?" (ibid.). ${ }^{46}$

A vantagem da nova fórmula é que totalidade afirmativa é um atributo exclusivamente divino (ubíquo e total), em contraste com a criatura, como totalidade negativa ("nada"). A nova fórmula parece mais precisa, mas não menos enigmática. Seu papel consiste em relançar o vórtice de perguntas. Por ora, parece que invocar (e louvar) Deus é um ato sem sustentação teórica. $\mathrm{O}$ fracasso das explicaçôes examinadas vai conduzindo para a impossibilidade da invocação, ou melhor, para uma invocação impossível.

\section{A invocação impossivel}

Face à impossibilidade teórica do louvor e da invocação, o orador pergunta: "o que és, então meu Deus?”. Aqui se fundem os dois planos, louvor e invocação, linguagem e ser. A pergunta inaugura uma nova prece, uma prece impossível, mas ainda assim uma prece. ${ }^{47} \mathrm{~A}$ impossibilidade dá lugar a uma prece paradoxal, que toma todo um parágrafo (Confissóes I iv 4), estruturada em paradoxos, antíteses, oximoros, como que sugerindo a conclusão a ser tirada das dificuldades mobilizadas até aqui. A prece retoma os problemas postos em relevo até o momento, numa rapsódia de técnicas da chamada "teologia negativa”, que parece conduzir à simples conclusão da inefabilidade divina.

\footnotetext{
45 "sed quae imples omnia, te toto imples omnia."

46 "an ubique totus es et res nulla te totum capit?"

47 "Invocation at last", dirá O’Donnell.
} 
É sim possível entrever, aqui neste testemunho da chamada "teologia negativa", uma abertura para a predicação afirmativa de Deus. ${ }^{8}$ Não obstante, agora importa sublinhar que o resultado apofático, negativo, é aventado pelo próprio Autor, como se fosse essa a consequência quase inevitável dos embaraços encontrados, como se fosse a única resposta ao impasse: negaçáo e finalmente silêncio. "Mas o que dizemos, meu Deus, minha vida, minha santa doçura, e o que diz qualquer um quando fala de ti?" (Confissóes I iv 4$)^{49}$

A procura do fundamento teórico incorre neste risco importante. Ao inverter o sentido tradicional da prece, e ativar a inquietude humana com recursos habitualmente pacificadores, o Autor vai conduzir a uma aporia, sob o risco de tornar inviável a tarefa auto-imposta. A minuciosa elaboração de um impasse poderá desembocar no contrário do que se espera: ao invés de diálogo, um silêncio impotente.

Em suma, o uso paradoxal de duas formas de discurso por si mesmas alheias à reflexão filosófica, a oratória e a prece religiosa, parece conduzir quando muito ao discurso apofático. Náo seria o resultado inexorável da pretensão de transformar em instrumento teórico a prece, exemplo mesmo do discurso que não é apofântico?so Qual será afinal o propósito da combinação da retórica do panegírico com as fórmulas de louvor e invocação de deuses? Se quisermos aqui enxergar um uso protréptico da linguagem, como se o leitor fosse instado a reconhecer problemas especulativos ali onde percebia a princípio clichês pacificadores, o resultado poderia ser tão-somente um impasse e, afinal, o silêncio.

\section{"Mas deixa-me falar"}

A possibilidade de condenação ao silêncio é na verdade uma forma renovada de inquietude. O impasse torna-se o problema a ser investigado: como dialogar com um Deus inefável, que está além da linguagem? Reafirma-se aqui porém o imperativo do início: "nosso coração é inquieto até repousar em ti". O silêncio seria um mau resultado da investigação, de modo que o Autor mantém-se inquieto: “quem me fará repousar em ti?"’r

O desfecho do prólogo, que combina a consciência da condição quase desesperada e o projeto renitente de uma linguagem ainda possível, está condensado na última alusão bíblica do prólogo. "Mas deixa-me falar à tua misericórdia, eu, terra e cinza, deixa contudo que eu fale" (Confissóes I vi 7)..$^{2}$ Agostinho alude a Abraão, que no limiar da destruição de Sodoma insiste em negociar com Deus, mesmo consciente de sua miséria. ${ }^{33}$

48 Cf. Novaes, M. A razão em exercício. Estudos sobre a filosofia de Agostinho. Coleção Philosophia. São Paulo: Discurso Editorial e ed. Paulus, 2009 ( $2^{\mathrm{a}}$. edição), pp. I34 ss.

49 "et quid diximus, deus meus, vita mea, dulcedo mea sancta, aut quid dicit aliquis cum de te dicit?"

50 Cf. Aristóteles, De interpretatione iv, I6b 33.

5I V. nota I7 supra. A inquietude agora já associada ao problema da invocaçáo. O homem quer repousar em Deus [in te], e aspira a que venha nele [in cor meum]: "Quem fará com que tu venhas ao meu coração e o inebries?". Confissóes I v 5: "quis dabit mihi ut venias in cor meum [...]?”

52 "sed tamen sine me loqui apud misericordiam tuam, me terram et cinerem sine tamen loqui." (Confissóes I vi 7 , cf. Gênesis I8, 27). Podemos ler as sentenças iniciais do $\$ 7$ como passagem do prólogo à narrativa.

53 A alusão talvez se estenda às frases seguintes, que encerram o prólogo. O tema do riso de espanto, ou de descrédito, marca o diálogo entre Abraão e Deus, e entre Abraão e Sara: cf. Gênesis I7, I7; I8, 2; 2I, 6 . 
O Autor também insiste, quer falar, e precisa encontrar as condições a partir do impasse que ele mesmo encontrou, ou engendrou.

Os novos paradoxos e conflitos do célebre quarto parágrafo terão assim duplo alcance, segundo a estratégia do diálogo filosófico. As sucessivas perguntas que o compóem, entremeadas por fórmulas antitéticas e/ou negativas, antecipam temas a serem enfrentados nos livros subsequentes, nas seçôes narrativa e exegética; desse modo, dispóem um temário a ser desenvolvido no correr da obra. Mas seu papel específico é gerar o impasse do qual resultarão as diretrizes para o oportuno enfrentamento do problema. Enquanto, até ali, a prece em oximoros poderia levar ao silêncio sobre Deus - "e o que diz qualquer um, quando fala de ti?" - o parágrafo é encerrado com uma frase que pareceria reiterar a precedente, como condenação ao silêncio total: "ai dos que se calam sobre ti, porque, mesmo falando, são mudos” (Confissóes I iv 4).54

Se sou obrigado a silenciar sobre Deus, toda fala será mera loquacidade, e como tal será muda, silenciosa sobre a verdade. $\mathrm{O}$ que cala sobre Deus, ainda que loquaz, será mudo. Mas a questão na verdade agora é: será preciso calar sobre Deus? Será essa a consequência? Ou, em face do imperativo do diálogo, ainda assim temos de procurar a comunicação verbal com Deus, verdade e sabedoria supremas? Se tomarmos a invocação naquele sentido da articulação de dois conhecimentos, crer e entender, o papel dessa prece peculiar será justamente o de apresentar um horizonte de interrogação, precário por natureza.

Com efeito, se o silêncio não pode ser o resultado, parece-nos correto ler aquela última sentença, "ai dos que se calam...", como nova virada no argumento, razão a mais para a inquietação crescente. Ao invés de ser reiteração da inefabilidade, e condenação ao silêncio total, a frase pode ser lida como inversão de expectativa. $\mathrm{O}$ silêncio sobre Deus não é a boa consequência a ser extraída das aporias. Se falar de Deus é impossível, aquele que não fala de Deus, mas fala de outras coisas, é que é verdadeiramente mudo. O loquaz mudo é aquele que usa a linguagem, mas renuncia a falar de e com Deus. Ao inverso, é imperativo falar sobre Deus, ainda que ele seja inefável.

Somos levados mediante paradoxos a um risco de silêncio peculiarmente paradoxal. Num primeiro plano, o paradoxo estaria em dizer que o inefável é inefável. Mas agora se trata de um paradoxo à segunda potência: constatar o inefável, e reconhecer com ele o imperativo de procurar a comunicação com o inefável.

\section{Do que não se pode falar...}

A solução do impasse, sem a qual não seria legítimo o desenrolar da obra, decorre de duas coisas: genericamente, decorre de contar com a misericórdia divina; e especificamente, decorre de saber como receber a misericórdia divina, nos termos da legitimidade do uso

54 "vae tacentibus de te, quoniam loquaces muti sunt." A frase oferece dificuldades de interpretação e tradução. James O’Donnell, em minucioso comentário, no II volume de sua edição das Confissóes, Augustine (1992), exibe uma diversidade de leituras e traduçóes, a partir do oximoro "loquaces muti". "The oxymoron [...] has puzzled", p. 27. 
da palavra. Genericamente, pois, a trava no diálogo não será removida pelo homem. O limite de suas forças estampara-se na última tentativa de prece invocatória (I iv 4). A trava, espera-se, será removida pela misericórdia divina: "Tem piedade para que eu fale" ("miserere ut loquar" Confissóes I v 5).

Mas como encontrar as condiçôes de possibilidade do diálogo, com base na compaixão de Deus? Para prosperar, o Autor examina os polos do diálogo emperrado, repete a estratégia de enumerar perguntas, agora sobre si e sobre Deus. Porém, a saída para o impasse estará não em novas perguntas, mas num pedido. Na verdade, trata-se de transformar as perguntas, concentrá-las em um pedido peculiar, que inverte a estratégia adotada até o momento. As perguntas interrogam quem são Deus e o homem, agora como polos relativos: Deus para mim, eu para Deus. "O que és tu para mim? [...] O que sou eu para ti [...]?” (Confissóes I v 5).55

Em vez de continuar a perguntar, o pedido leva em conta que o diálogo pretendido terá dois polos. Em vez de insistir numa palavra que não funciona, cabe agora pedir para que Deus fale. Vale dizer, o pedido é que a misericórdia de Deus o torne capaz de ouvir uma fala já existente. Trata-se de tomar os "atos [divinos] de misericórdia" como voz, como linguagem. Ao pedir para que Deus diga algo, o Autor transforma sua posição no diálogo. Seu lugar será então de audição, e somente enquanto audição, terá nova voz, desta vez secundária, decorrência do efeito da voz divina, se e quando adequadamente ouvida. Em primeiro lugar, pois, a contraparte humana no diálogo, até aqui intentada como fala, e reiteradamente emperrada, torna-se certa escuta, da qual emergirá outra voz humana. ${ }^{6}$ "Dize-me pelos teus atos de misericórdia [...]. Dize-o, para que eu ouça. [...] Correrei atrás dessa voz e te alcançarei” (Confissóes I v 5).57

Como ouvir a voz divina, e transformá-la em discurso legítimo? Trata-se aqui de estabelecer um objeto privilegiado de análise e de indicar as condiçóes subjetivas da escuta. Conforme a narrativa dos Livros I a IX exibirá em pormenor, o Autor tomará a sua vida fática como expressão da providência divina. Narrá-la desse modo será por si mesmo uma interpretação e uma resposta à misericórdia de Deus. Se o homem não tem condiçóes de um diálogo propriamente com Deus, resta-lhe ao menos provisoriamente o chamado "diálogo hermenêutico" ${ }^{8}{ }^{8}$ Cada interpretação (humana) será resposta à voz (divina) contida nos fatos, agora finalmente ouvida.

55 "Quid mihi es? [...] quid tibi sum ipse [...]?"

56 Movimento semelhante encontra-se na Enarratio in Psalmum 38, 4 : "Porque ao temer em excesso [...] não dizer coisas boas, [Iditun] resolveu nada dizer, nem mesmo coisas boas; e como resolveu calar, começou a náo escutar." Devo a indicação a E. Bermon, em conferência organizada por Cristiane Abbud-Ayoub, na Ufabc. Bermon remete a J.-L. Chrétien, Saint Augustin et les actes de parole. Paris: PUF, 2002.

57 "dic mihi per miserationes tuas [...]. sic dic ut audiam. [...] curram post vocem hanc et apprehendam te."

58 Sobre essa forma incipiente de diálogo, mediante a interpretação da ação providencial divina, ou diálogo hermenêutico, cf. Herzog, 1984, pp. 218 ss. 
Outra "voz" divina chegará ao "ouvido" interno, desta vez mediante a leitura e interpretação da Bíblia. A narrativa exibirá também um vetor progressivo de apropriação, a par de outras leituras literárias e filosóficas. Como exibiu o manejo das citaçóes já no prólogo da obra, a escuta dessa voz particular exigirá igualmente inspeção e distanciamento (ainda que, por ora, a capacidade de leitura tenha se mostrado útil somente para reconhecer aporias). Apresenta-se assim uma nova forma de diálogo, ainda que precária, na qual a contraparte humana será uma voz secundária, dependente de outra voz e da escuta. Para tanto, além da eleição do objeto de escuta, é preciso interrogar sobre quem escuta e como escuta. Para ouvir, é preciso mobilizar e constituir o "ouvido do coração": "Eis diante de ti os ouvidos do meu coraçáo" (Confissóes I v 5).99

Também aqui podemos indicar como a narrativa dará seguimento ao propósito enunciado. "Ouvir com o coração" vai significar dar prioridade à inspeção de si mesmo, da evolução de seu intelecto, de sua vontade, uma análise minuciosa dos movimentos e decisóes da alma. Tanto a história intelectual, como uma minuciosa patética ganharáo sentido como esforço de fazer do comentário da vida interna (adesôes filosóficas ou ceticismo, escolhas de interlocutores e de leituras, amores, amizades, paixóes, hesitaçóes e decisóes) uma resposta à dinâmica externa conduzida por Deus. ${ }^{60}$

Por outro lado, o ouvido do coração requer a escuta distanciada, refinada, conforme terá aprendido com as explicaçôes "espirituais” de Ambrósio (cf. Confissóes vi iv 5-6). Para além da sua formação como leitor da Bíblia na parte narrativa, a nova disposiçáo do ouvido interno ganhará relevo na parte exegética, a exemplo do Livro XI, onde a análise do tempo vai privilegiar a linguagem temporal de modo a realizar uma singular inspeção do espirito.

\section{Conclusão}

A interpretação das Confissóes como elogio do diálogo parece assim justificar-se. O elogio do diálogo faz-se pelo seu conteúdo, uma vez que o prólogo realça o diálogo entre Deus e o homem como necessário tema de investigação, desdobramento da inquietude incitada pelo próprio Deus. Esse deverá ser uso legítimo da linguagem, segundo condiçôes de possibilidade tão-somente esboçadas. As aporias da inefabilidade, sem que sejam dissolvidas, dão ocasiáo a um reconhecimento preliminar de vozes diferentes, em cujo diálogo se entrevê uma alternativa. Isso implica, para a leitura da obra, atenção a essas vozes e à sua articulação.

Tanto na narração, como na exegese bíblica, haverá multiplicidade de vozes em diálogo, conforme outro aprendizado progressivo (mesmo nos livros náo narrativos). Por exemplo, o Autor (como narrador da autobiografia) renovará substancialmente o diálogo ao se dirigir a Deus na segunda pessoa, tomando distância do assunto imediato,

59 "ecce aures cordis mei ante te".

60 A "vida interna da alma" poderia ser interpretada também como parte de uma tríplice eloquência divina, ao lado da ação providencial e das escrituras. cf. DiLorenzo, I983, p. I26. 
narração ou exegese, e indagando pelo sentido e pelas condiçóes do que faz. Mas sobretudo outros interlocutores e outros diálogos devem apresentar-se, segundo o progresso mesmo da capacidade de dialogar do Autor (agora como herói da autobiografia).

Desse modo, o tema enunciado de início também se transforma. A procura do diálogo individual com Deus vai sendo mesclada ao reconhecimento da relevância de diálogos com outros na vida fática (do "herói"), e da pergunta (do "narrador") pela relevância da própria narrativa não somente frente a Deus, mas também frente aos homens. A arquitetura dos livros finais, recorrendo a uma diversidade de intepretaçóes, diversas da do próprio Autor, renovará o tema do diálogo como núcleo de preocupações das Confissóes.

Também a estrutura formal da obra será um testemunho do elogio do diálogo. Podemos identificar o roteiro que vai do impasse inaugural à retomada final do tema, passando por um périplo propedêutico. $\mathrm{O}$ prólogo terá cumprido o seu papel ao não apenas suscitar a inquietude mediante as aporias, mas também por assinalar exigências precisas a serem observadas no desdobramento da obra. Além disso, parece próprio do "gênero" diálogo que a indagação inicial também seja transformada entre o desvio propedêutico e a parte final.

Náo podemos esquecer que a invocação, que volta renitente no $\$ 5$, esbarrara na onipresença divina. Enquanto esta não for compreendida, segundo as exigências de "saber e compreender" (scire et intellegere), tampouco estará superada a ideia de distância entre Deus e o homem, que motivaria invocar. Os dois temas ainda carecem de explicação. Nesse caso, a existência de um caminho alternativo, como voz alternativa que respondesse à onipresença divina, em regime interno, terá de levar em conta o estado presente do "ouvido interno", estado que envolve aquela distância ainda incompreendida. Isto é, o exame das condiçôes de possibilidade do diálogo, agora com base nas vozes divinas, requer atenção àquela distância ainda não esclarecida, mas sempre relevante.

Por isso, a eleição do espaço interno, o "coração", para ser o ouvido adequado não significa que ele já esteja pronto. Sua natureza é limitada e está em más condições, aquém da plenitude de sua natureza ('casa pequena e em ruínas' cf. $\$ 6$ ). A legitimidade da voz humana ainda está por se afirmar. O termo "confissão" não pode levar a engano. O reconhecimento da miséria não pretende legitimar-se como ato jurídico, como a confissão segundo regras de um tribunal. Aqui a voz que confessa não pode esperar leniência ou perdão: "não discuto teu julgamento" (Confissóes I v 6). ${ }^{61}$ A constituição e legitimação da voz humana dialogal terá de esperar o desdobramento da obra. Por ora, a persistência é similar à de Abraão: "Mas deixa-me falar à tua misericórdia, eu, terra e cinza". ${ }^{62}$ Ainda náo vemos propriamente o que pode autorizar a palavra humana. Isso quer dizer que o processo de escuta e de uso da voz secundária será ao mesmo tempo resultante e transformador do espaço interno. A narração que se anun-

6I "non iudicio contendo tecum". Em proveito desta interpretação, como exclusão de um específico regime confessional já legitimado, talvez se pudesse traduzir: "não é no tribunal que discuto contigo".

62 Cf. nota 52 supra. 
cia será uma decodificação progressiva da voz divina, presente nas ações providenciais, porque o narrador será afetado e deverá aprimorar sua capacidade de escuta e de fala. Deve-se esperar pois que o Autor (narrador e herói) aprenda a dialogar, como se vê na narrativa de um diálogo, ainda incompleto, ocorrido no período de Cassicíaco. Náo os diálogos travados à época e depois publicados pelo Autor (contra academicos etc.), mas um diálogo que surge relatado no Livro Ix das Confissóes.

A leitura do Salmo 4, a que nos referimos no início, é relatada ao longo de páginas. Mas na verdade, o relato ali não é da leitura como acontecimento material, recitação dos dez versos. Na verdade o Salmo é interpretado demoradamente (Confissóes ix iv 8-I2), escandido verso a verso, utilizado como suporte para discriminar e articular um possível diálogo. A "leitura" pela narrativa é feita de modo a identificar na sucessão de versículos uma diversidade de vozes: Deus, Agostinho e seus opositores maniqueístas. O episódio é relatado ao longo de páginas, como dissemos acima, porque ao assim interpretar aqueles poucos versículos, o Autor vai indicando, já no fim da seção narrativa de sua autobiografia, como está em processo de aprendizagem: já consegue tomar a Bíblia não como suporte doutrinal de suas próprias teses, mas como material de articulação de sua voz com a de Deus e também com a de seus antagonistas.

Não será essa a palavra final em termos de utilidade da Bíblia como diálogo e para o diálogo filosófico, mas já é um passo. O próprio narrador sublinha que naquele momento, ao cantar o Salmo, não teria sabido realizar esse diálogo. O importante agora é assinalar que não se trata mais de opor os diálogos filosóficos do jovem Agostinho à escolha da Bíblia pelo Bispo de Hipona. Na verdade, são duas formas de diálogo, em progresso. $\mathrm{O}$ aprendizado ali esboçado anuncia o sentido da meditação exegética dos livros finais. Como a narrativa propiciou o progresso para essa forma de diálogo, ainda incipiente, e deu impulso ao verdadeiro diálogo dos livros XI-XIII, trataremos em trabalhos a seguir.

\section{Referências bibliográficas}

Augustine (1992). Confessions, text and commentary by James J. O’Donnell, Oxford [acessível em www.stoa.org/hippo/].

Agostinho (20i8). Confissóes. Tradução e prefácio de Lorenzo Mammì. $2^{a}$ ed., Sáo Paulo: Penguin Classics \& Companhia das Letras.

Auerbach, E. (20I2). Ensaios de literatura ocidental: filologia e critica (org. D. Arrigucci Jr. e S. Titan Jr.; tradução S. Titan Jr. e J. M. Mariani de Macedo). Sáo Paulo: Duas cidades e Editora 34.

Bailey, C. (1969). Religion in Virgil, New York: Barnes and Noble.

Bermon, E. (200I). Le cogito dans la pensée de saint Augustin. Paris: J. Vrin.

(2018). Les apories des confessions augustiniennes. Texto inédito. Conferência apresentada em Io de abril de 2018 na Universidade Federal do ABC.

Binns, J. W. (1974). (ed.) Latin Literature of the Fourth Century, London and Boston: Routledge \& Kegan Paul. 
Brown, P. (2005). Santo Agostinho, uma biografia. Rio de Janeiro e São Paulo: Record.

Comparetti, D. (1966). Vergil in the Middle Ages. London: George Allen and Unwin.

Courcelle, P. (1952). "Source chrétienne et allusions païennes de l'épisode du 'Tolle lege'." In: Revue d'histoire et de philosophie religieuse 32, pp. 171-200.

(1963). Les Confessions de saint Augustin dans la tradition littéraire. Antécédents et Postérité. Paris: Études Augustiniennes.

DiLorenzo, R. (1983). "Non pie quaerunt: Rhetoric, Dialectic, and the Discovery of the True in Augustine's Confessions." In: Augustinian Studies I4, pp. II7-I27.

Goldschmidt, V. (1947). Les dialogues de Platon. Structure et méthode dialectique. Paris: Presses Universitaires, .

Herzog, R. (1984). "Non in sua voce: Augustins Gespräch mit Gott in den Confessiones - Voraussetzungen und Folgen" In: Poetik und Hermeneutik II, pp. 213-250.

Hickson, F. (1993). Roman prayer language: Livy and the Aneid [sic] of Vergil (Beiträge zur Altertumskunde, 30). Stuttgart: Teubner.

Maguinness, W. (1933). "Locutions and Formulae of the Latin Panegyrists" In: Hermathena 48, pp. II7-I38.

Mohrmann, Chr. (1955). "Problèmes stylistiques dans la littérature latine chrétienne." In: Vigiliae Christianae 9, pp. 222-246.

Rees, R. (2004). (ed.) Romane Memento: Vergil in the Fourth Century, London: Duckworth.

Rodgers, B. (1986). "Divine Insinuation in the Panegyrici Latini." In: Historia: Zeitschrift für Alte Geschichte 35, pp. 69-104.

RüPke, J. (2007). (ed.) A Companion to Roman Religion. Oxford: Blackwell.

Sandnes, K. (20II). The Gospel According to Homer and Virgil': Cento and Canon. Leiden and Boston: Brill.

Scheid, J. (20II). Quand faire, c'est croire: les rites sacrificiels des Romains. Paris: Aubier, Flammarion.

Wieland, W. (1982). Platon und die Formen des Wissens, Göttingen: Vandenhoeck \& Ruprecht. 